\title{
PROPORSIONALITAS PENJATUHAN PIDANA
}

\section{Eva Achjani ${ }^{1}$}

\begin{abstract}
Various factors may be the cause of any disparity. In Indonesia, the biggest problem of sentencing disparity is so large and diverse. As the experience of many countries, to formulate a guideline sentencing is not an easy job. Various models based on the strategy formulation sentencing guidelines as stated earlier sanctions have been tried, ranging from very tight to very loose. In America for example, the difference between those who are white will get different treatment to those colored in the criminal justice process, including the decision handed down. Differences due to gender where male inmates allegedly obtaining a higher penalty than the convict women. In Indonesia, the biggest problem of sentencing disparity is so large and diverse as stated earlier.
\end{abstract}

Keywords: punishment, disparity, judges

\begin{abstract}
Abstrak
Berbagai faktor dapat saja menjadi sebab terjadinya disparitas pemidanaan. Di Indonesia, problema terbesar dari pemidanaan adalah disparitas yang begitu besar dan beragam. Sebagaimana pengalaman diberbagai Negara, merumuskan suatu pedoman pemidanaan bukanlah suatu pekerjaan yang mudah. Berbagai model pedoman pemidanaan berdasarkan strategi perumusan sanksi sebagaimana dikemukakan terdahulu telah dicoba, mulai dari yang sangat ketat hingga yang sangat longgar. Di Amerika misalnya perbedaan antara mereka yang berkulit putih akan memperoleh perlakuan yang berbeda dengan mereka yang berkulit berwarna dalam proses peradilan pidana termasuk terhadap putusan yang dijatuhkan. Perbedaan karena jenis kelamin dimana ditengarai terpidana pria memperoleh hukuman yang lebih tinggi daripada terpidana wanita. Di Indonesia, problema terbesar dari pemidanaan adalah disparitas yang begitu besar dan beragam sebagaimana telah dinyatakan terdahulu.
\end{abstract}

Katakunci: pemidanaan, disparitas, hakim

\footnotetext{
${ }^{1}$ Penulis adalah Staf Pengajar FHUI. Alamat kontak: evazulfa@ui.ac.id.
} 


\section{Disparitas Pemidanaan}

Masalah disparitas pemidanaan menjadi pertanyaan utama yang berkaitan erat dengan pertanyaan apakah suatu putusan hakim sudah memenuhi rasa keadilan. Muladi menyebutnya sebagai "disturbing issue" dalam berbagai Sistem peradilan pidana. $^{2}$ Sementara Harkristusi Harkrisnowo menyatakan bahwa masalah ini sebagai "universal issue" yang kerap melanda berbagai Sistem peradilan pidana. ${ }^{3}$ Masalah disparitas pemidanaan muncul apabila kita membandingkan penjatuhan sanksi pidana satu putusan hakim dengan putusan hakim lainnya.

Makna disparitas atau disparity berarti Inequality; a defference in quantity or quality between two or more things. ${ }^{4}$ Alfred Blumstein mendefinisikannya sebagai $a$ form of anequal treatment that is of often of unexplained cause and is at least incongrous, unfair and disadvantaging in consequence. ${ }^{5}$ Makna disparitas pemidanaan akan tercermin dari putusan jumlah pidana yang dijatuhkan atas satu pelanggaran hukum yang sama, misalnya dua orang pencuri yang sama-sama memenuhi unsur dalam Pasal 362 namun memperoleh hukuman yang berbeda. Karenanya disparitas pidana dapat dipahami sebagai suatu keadaan yang berkenaan dengan adanya perbedaan dalam penjatuhan pidana untuk kasus yang serupa atau setara keseriusannya, tanpa ada alasan pembenaran yang jelas. ${ }^{6}$

Contoh A memperoleh sanksi penjara selama 3 tahun sementara B dipidana selama 6 bulan. Persoalan disparitas akan mengemuka terhadap kasus-kasus yang menjadi sorotan publik atau yang nilai kerugian yang ditimbulkan besar. Misalnya bila dibandingkan antara seorang pencuri yang melakukan pencurian sebagaimana dirumuskan dalam Pasal 362 KUHP dengan seorang koruptor yang merugikan

${ }^{2}$ Muladi, "Kapita Selekta Sistem Peradilan Pidana", Cet.1. (Semarang: Badan Penerbit Universitas Diponegoro, 1995), hal. 80.

${ }^{3}$ Harkristuti Harkrisnowo, Rekonstruksi Konsep Pemidanaan: Suatu Gugatan Terhadap Proses Legislasi dan Pemidanaan di Indonesia, Orasi Pengukuhan Guru Besar di Universitas Indonesia, (Depok: 8 Maret 2003), hal. 7.

${ }^{4}$ Bryan A.Garner (Ed), “Black's Law Dictionary", 7 edition, (St.Paul, Minn, 2000), hal. 381.

${ }^{5}$ Alfred Blumstein et al, Research on Sentencing: The Search for Reform, Volume II (1983), ditelusur melalui http://book.nap.edu/openbook_php?record_id=101\&page=9

${ }^{6}$ Harkristuti Harkrisnowo, Op. Cit. 
keuangan Negara hingga milyaran rupiah namun keduanya sama-sama dijatuhi pidana 4 tahun penjara atau bahkan bagi sang koruptor dipidana lebih rendah.

Disparitas pemidanaan dapat terjadi karena banyak faktor. Beccaria, dalam adagium yang dirumuskannya sebagai "let punishment fir the crime", mengakui bahwa setiap perkara pidana memiliki karakteristiknya sendiri yang disebabkan karena kondisi pelaku, korban ataupun situasi yang ada pada saat tindak pidana terjadi. Karenanya hakim yang melihat perkara ini tentu saja tidak dapat menutup mata dalam mempertimbangkan berbagai faktor tersebut.

Berbagai faktor dapat saja menjadi sebab terjadinya disparitas pemidanaan. Masalah-masalah seperti perbedaan ras, gender, status sosial, pandangan politik dan lain sebagainya dapat menjadi hal yang mempengaruhi hakim dalam menjatuhkan sanksi pidana. Masalah diskriminasi di beberapa Negara menjadi faktor yang menyebabkan disparitas terjadi. Di Amerika misalnya perbedaan antara mereka yang berkulit putih akan memperoleh perlakuan yang berbeda dengan mereka yang berkulit berwarna dalam proses peradilan pidana termasuk terhadap putusan yang dijatuhkan. Perbedaan karena jenis kelamin dimana ditengarai terpidana pria memperoleh hukuman yang lebih tinggi daripada terpidana wanita. Kelas sosial dalam masyarakat dimana para pejabat mendapatkan perlakuan istimewa termassuk hukuman yang lebih ringan daripada orang kebanyakan. Atau orientasi seksual khususnya dalam perkara kesusilaan, hakim perempuan misalnya akan menjatuhkan sanksi yang lebih tinggi bagi pelaku perkosaan dibandingkan dengan hakim laki-laki.

Masalah kebebasan hakim dalam memutuskan perkara pidana yang ditanganinya menjadi faktor yang juga menimbulkan terjadinya disparitas pemidanaan. Di Indonesia asas kebebasan hakim (judicial discretionary power) dijamin sepenuhnya dalam Pasal 1 Undang-undang No.4 tahun 2004 tentang Kekuasaan Kehakiman dimana dirumuskan bahwa kekuasaan kehakiman adalah kekuasaan negara yang merdeka untuk menyelenggarakan peradilan guna menegakkan hukum dan keadilan berdasarkan Pancasila, demi terselenggaranya Negara Hukum Republik Indonesia. Hakim sebagai penyelenggara kekuasaan kehakiman memperoleh kewenangan untuk memeriksa dan memutus perkara pidana yang ditanganinya secara bebas dari intervensi pihak manapun.

Namun demikian dalam hal menjatuhkan sanksi pidana, kebebasan hakim bukanlah tanpa batas. Asas Nulla Poena Sine Lege, dimana hakim hanya dapat memutuskan sanksi pidana berdasarkan jenis dan berat sanksi sesuai dengan takaran yang ditentukan oleh undang-undang. Asas yang merupakan bagian dari Asas legalitas yang diatur dalam Pasal 1 ayat 1 KUHP. Namun demikian meski batasan ini ditetapkan, standart antara batas minimal dan maksimal dari sanksi pidana yang ditentukan oleh undang-undang terlampau besar sehingga problema disparitas 
pemidanaan menjadi mengemuka. Dalam jenis pidana penjara misalnya Pasal 12 KUHP ditentukan bahwa pidana penjara sementara waktu paling singkat 1 hari dan paling lama 15 tahun. Ini adalah batasan minimal umum dan maksimal umum yang berlaku dalam KUHP. Sementara dalam pasal-pasal yang terdapat dalam Buku II KUHP, menentukan maksimum khusus untuk sanksi pidana yang dapat dijatuhkan bagi masing-masing jenis tindak pidana. Misalnya 5 tahun untuk tindak pidana pencurian (Pasal 362 KUHP), 12 tahun untuk tindak pidana perkosaan (Pasal 285 KUHP) atau 3 bulan untuk tindak pidana penganiayaan ringan (Pasal 352 KUHP). Diluar KUHP, berbagai undang-undang mengatur secara tersendiri misalnya ancaman pidana dalam Undang-Undang Pelanggaran Berat HAM menentukan sanksi minimal penjara 10 tahun sampai dengan maksimal hukuman mati, Undang-Undang Narkotika menentukan sanksi minimal pidana penjara 4 tahun sampai dengan maksimal hukuman mati, atau Dalam Undang-Undang Pemberantasan Tindak Pidana Korupsi yang menentukan pidana penjara minimal 4 tahun dan maksimal hukuman mati.

Dalam kenyataannya sangat jarang hakim yang menjatuhkan pidana maksimal. Harkristuti menggambarkan sanksi pidana yang kerap dijatuhkan hakim untuk beberapa jenis tindak pidana sebagai berikut: ${ }^{7}$

\begin{tabular}{|c|c|c|c|}
\hline \multirow[t]{2}{*}{ Tindak Pidana } & \multicolumn{2}{|c|}{$\begin{array}{l}\text { Sanksi Pidana Pokok dalam } \\
\text { Undang-Undang }\end{array}$} & \multirow[t]{2}{*}{$\begin{array}{ll}\text { Pidana } & \text { yang } \\
\text { dijatuhkan } & \end{array}$} \\
\hline & Minimal & Maksimal & \\
\hline Pelanggaran Berat HAM & Penjara 10 th & Mati & 3 th \\
\hline Korupsi & Penjara 4 th & Mati & 3 th - pidana mati \\
\hline Narkotika & Penjara 4 th & Mati & 1 th-pidana mati \\
\hline Pembunuhan Berencana & Penjara $1 \mathrm{hr}$ & $\begin{array}{l}\text { Penjara } 20 \text { th, } \\
\text { seumur hidup, } \\
\text { mati }\end{array}$ & 3 th - pidana mati \\
\hline Pencurian dengan Kekerasan & Penjara $1 \mathrm{hr}$ & $\begin{array}{l}\text { Penjara } 9 \text { th, } \\
20 \text { th, seumur } \\
\text { hidup, mati }\end{array}$ & $2-12$ th \\
\hline Pembunuhan & Penjara $1 \mathrm{hr}$ & Penjara 15 th & $3-12$ th \\
\hline Penganiayaan Berat & Penjara $1 \mathrm{hr}$ & 12 th & 15 bln -7 th \\
\hline Perkosaan & Penjara $1 \mathrm{hr}$ & 12 th & 2 bln -6 th \\
\hline Pencurian & Penjara $1 \mathrm{hr}$ & 5 th & 2 bln -6 th \\
\hline
\end{tabular}

Sumber: Harkristuti Harkrisnowo, Orasi Guru Besar, 2003.

${ }^{7}$ Ibid. 
Untuk mendapatkan gambaran yang lebih baik terkait dengan pola penjatuhan pidana oleh hakim, penulis mengambil beberapa contoh putusan yang kemudian dikelompokkan dalam kualifikasi tindak pidana yang sama yaitu kelompok tindak pidana kekerasan dalam rumah tangga, korupsi dan narkotika. Hasil perbandingan tersebut menunjukangambaran sebagai berikut:

Dalam kasus KDRT, beberapa putusan menggambarkan pola penjatuhan pidana sebagai berikut:

\begin{tabular}{|l|l|l|l|}
\hline No. & No. Register Perkara & $\begin{array}{l}\text { Ancaman Pidana Dalam } \\
\text { Undang-Undang }\end{array}$ & $\begin{array}{l}\text { Sanksi Yang Dijatuhkan } \\
\text { Hakim }\end{array}$ \\
\hline 1. & 255/Pid.B/2006/PN.SLMN & $\begin{array}{l}\text { Maks. Penjara 3 tahun } \\
\text { atau denda Rp.18 juta }\end{array}$ & $\begin{array}{l}\text { Penjara 3 bulan dengan } \\
\text { masa pencobaan 6 bulan }\end{array}$ \\
\hline 2. & $01 /$ Pid B/2009/PN.YK & $\begin{array}{l}\text { Maks. Penjara 3 tahun } \\
\text { atau denda Rp.18 juta }\end{array}$ & bulan \\
\hline 3. & $982 /$ Pid.B/2008/PN.DPS & $\begin{array}{l}\text { Maks. Penjara 3 tahun } \\
\text { atau denda Rp.18 juta }\end{array}$ & $\begin{array}{l}\text { Penjara 6 bulan dengan } \\
\text { masa percobaan 1 tahun }\end{array}$ \\
\hline 4. & $653 /$ Pid B/2007/PN.Smg & $\begin{array}{l}\text { Maks. Penjara 3 tahun } \\
\text { atau denda Rp.18 juta }\end{array}$ & Penjara 3 bulan \\
\hline
\end{tabular}

Dari keempat putusan tersebut tidak satupun putusan hakim yang menjatuhkan pidana dalam hitungan tahun. Seluruhnya hanya menjatuhkan pidana dalam hitungan bulan berkisar antara 2 bulan- 3 bulan. Terdapat ancaman pidana lebih dari 3 bulan penjara yaitu 6 bulan namun bentuk pidananya berupa pidana bersyarat dengan masa percobaan 6 bulan -1 tahun.

Dalam kasus Korupsi, beberapa putusan menggambarkan pola penjatuhan pidana sebagai berikut:

\begin{tabular}{|r|l|l|l|}
\hline No. & No. Register Perkara & $\begin{array}{l}\text { Ancaman Pidana Dalam } \\
\text { Undang-Undang }\end{array}$ & $\begin{array}{l}\text { Sanksi Yang Dijatuhkan } \\
\text { Hakim }\end{array}$ \\
\hline 1. & 534/Pid.B/2006/PN.SLMN & $\begin{array}{l}\text { Penjara seumur hidup, atau } \\
\text { min. 4 tahun dan mak. 20 } \\
\text { tahun, dan denda min. Rp. } \\
200 \text { jt dan mak. Rp. 1 } \\
\text { milyar. }\end{array}$ & $\begin{array}{l}\text { Penjara 5 tahun dan } \\
\text { denda 200 jt subsider 3 } \\
\text { bulan kurungan }\end{array}$ \\
\hline 2. & 146/Pid.B/2008/PN.Wt & $\begin{array}{l}\text { Penjara seumur hidup atau } \\
\text { min. 4 tahun dan mak. 20 } \\
\text { tahun, dan denda min. Rp. } \\
\text { 200 jt dan mak. Rp. 1 } \\
\text { milyar }\end{array}$ & $\begin{array}{l}\text { Penjara 5 tahun dan } \\
\text { denda 200 jt subsider 3 } \\
\text { bulan kurungan }\end{array}$ \\
\hline 3. & 52/Pid.B/2006/PN.Pbg & $\begin{array}{l}\text { Penjara seumur hidup atau } \\
\text { Penjara 1 tahun dan }\end{array}$ \\
\hline
\end{tabular}




\begin{tabular}{|c|c|c|c|}
\hline & & $\begin{array}{l}\text { min. } 4 \text { tahun dan mak. } 20 \\
\text { tahun, dan denda min. Rp. } \\
200 \text { jt dan mak. Rp. } 1 \\
\text { milyar }\end{array}$ & $\begin{array}{l}\text { denda } 50 \text { jt subsider } 3 \\
\text { bulan kurungan }\end{array}$ \\
\hline 4. & 116/Pid.B/2006/PN.Pbg & $\begin{array}{l}\text { Penjara seumur hidup atau } \\
\text { min. } 4 \text { tahun dan mak. } 20 \\
\text { tahun, dan denda min. Rp. } \\
200 \text { jt dan mak. Rp. } 1 \\
\text { milyar }\end{array}$ & $\begin{array}{l}\text { Penjara } 1 \text { tahun dan } \\
\text { denda } 575 \text { jt subsider } 2 \\
\text { bulan kurungan }\end{array}$ \\
\hline 5. & 485/Pid B/208/PN.DPS & $\begin{array}{l}\text { Penjara seumur hidup atau } \\
\text { min. } 4 \text { tahun dan mak. } 20 \\
\text { tahun, dan denda min. Rp. } \\
200 \text { jt dan mak. Rp. } 1 \\
\text { milyar }\end{array}$ & Penjara 1 tahun \\
\hline 6. & 174/Pid B/2005/PN & $\begin{array}{l}\text { Penjara seumur hidup atau } \\
\text { min. } 4 \text { tahun dan mak. } 20 \\
\text { tahun, dan denda min. Rp. } \\
200 \text { jt dan mak. Rp. } 1 \\
\text { milyar }\end{array}$ & $\begin{array}{l}\text { Penjara } 1 \text { tahun dan } \\
\text { denda Rp.50 jt }\end{array}$ \\
\hline
\end{tabular}

Fenomena yang dapat digambarkan dari keenam putusan pidana korupsi tersebut adalah 4 diantaranya menjatuhkan pidana dibawah ketentuan minimal khusus yang ditentukan oleh undang-undang. Undang-undang menentukan bahwa hukuman bagi seorang koruptor adalah minimal 4 tahun penjara, akan tetapi hakim hanya menjatuhkan 1 tahun penjara. Begitu pula kalau kita lihat konversi pidana denda menjadi pidana kurungan, maka polanya menjadi tidak seragam. Denda yang jumlahnya lebih besar justru mendapatkan pidana kurungan pengganti lebih singkat yaitu denda 575 jt subsider 2 bulan kurungan bandingkan dengan 50 jt subsider 3 bulan kurungan.

Dalam tindak pidana narkotika gambaran putusan hakim dapat dilihat sebagai berikut:

\begin{tabular}{|r|l|l|l|}
\hline No. & No. Register Perkara & $\begin{array}{l}\text { Ancaman Pidana Dalam } \\
\text { Undang-Undang }\end{array}$ & $\begin{array}{l}\text { Sanksi Yang } \\
\text { Dijatuhkan Hakim }\end{array}$ \\
\hline 1. & 374/Pid.B/2006/PN.Surabaya & $\begin{array}{l}\text { Maks. Penjara 15 tahun } \\
\text { dan denda min. Rp. 150 } \\
\text { juta rupiah dan maks. } \\
\text { Rp.750 jt rupiah. }\end{array}$ & $\begin{array}{l}\text { Penjara 3 tahun dan } \\
\text { denda 10 jt }\end{array}$ \\
\hline 2. & $1109 /$ Pid.B/2008/PN.DPS & $\begin{array}{l}\text { Maks. Penjara 15 tahun } \\
\text { dan denda min. Rp. 150 } \\
\text { juta rupiah dan maks. }\end{array}$ & $\begin{array}{l}\text { Penjara 6 bulan dan } \\
\text { denda Rp.2 jt subsider } \\
\text { 2 bulan kurungan }\end{array}$ \\
\hline
\end{tabular}




\begin{tabular}{|r|l|l|l|}
\hline & & Rp.750 jt rupiah. & \\
\hline 3. & 143/Pid.B/2009/PN.DPS & $\begin{array}{l}\text { Maks. Penjara 15 tahun } \\
\text { dan denda min. Rp. 150 } \\
\text { juta rupiah dan maks. } \\
\text { Rp.750 jt rupiah. }\end{array}$ & $\begin{array}{l}\text { Penjara 8 tahun 8 } \\
\text { bulan dan denda } \\
\text { Rp.15jt subsider 6 } \\
\text { bulan }\end{array}$ \\
\hline 4. & $\begin{array}{l}\text { Maks. Penjara 15 tahun } \\
\text { dan denda min. Rp. 150 } \\
\text { juta rupiah dan maks. } \\
\text { Rp.750 jt rupiah. }\end{array}$ & $\begin{array}{l}\text { Penjara 1 tahun 6 } \\
\text { bulan dan denda Rp.5 } \\
\text { jt subsider 6 bulan } \\
\text { kurungan }\end{array}$ \\
\hline
\end{tabular}

Hukuman tertinggi yang dijatuhkan hakim dalam tabel diatas adalah 8 tahun, artinya hanya separuh dari pidana maksimal yang diancamkan berdasarkan ketentuan undang-undang. Sementara tiga putusan lainnya hanya menjatuhkan pidana 3 tahun, 1 tahun bahkan 6 bulan. Sementara semua pidana denda yang dijatuhkan jauh dibawah denda minimal yang ditentukan dalam undang-undang. Undang-undang menentukan denda paling sedikit 150 juta rupiah namun hakim menjatuhkan denda antara 15 juta rupiah - 2 juta rupiah. Fenomena serupa dengan tindak pidana korupsi dimana konversi pidana denda menjadi pidana kurungan, maka polanya menjadi tidak seragam. Denda yang jumlahnya lebih besar justru mendapatkan pidana kurungan pengganti yang sama yaitu denda $15 \mathrm{jt}$ dan denda 5 jt sama-sama dikonversi 6 bulan kurungan.

Fenomena diatas pada dasarnya merupakan gambaran sederhana tentang permasalahn disparitas pemidanaan yang ada di Indonesia. Meskipun tidak dapat menjadi dasar untuk men-generalisir permasalahan ini namun perlunya pemikiran lebih lanjut untuk memperbaiki kondisi yang ada. Sesungguhnya dampak dari dispaitas pemidanaan akan mengancam upaya penegakan hukum itu sendiri. Dalam pandangan sosiologis, masalah ini dipahami sebagai suatu fenomena ketidak adilan (legal injustice) yang akan mengganggu rasa keadilan masyarakat (societal justice). ${ }^{8}$ Karena kesan negatif dan menurunnya tingkat kepercayaan masyarakat pada lembaga penegakan hukum menyebabkan kontrol sosial dalam masyarakat menjadi melemah. Munculnya ketidak percayaan akan keadilan (fairness), ketidak berpihakan (impartiality), dan kebebasan (independency) dari lembaga pengadilan. ${ }^{9}$

${ }^{8}$ Ibid.

${ }^{9}$ Ibid. 


\section{Penjatuhan hukuman yang Proporsional}

Di beberapa Negara, upaya yang dilakukan untuk meminimalisir perbedaan antar putusan pengadilan adalah dengan membuat suatu pedoman yang dapat menjadi rujukan bagi hakim dalam menjatuhkan sanksi pidana. Ide tentang penjatuhan pidana yang proporsional menjadi ide yang berkembang menjadi gagasan untuk membuat suatu pedoman pemidanaan yang mampu mereduksi subyektifitas hakim dalam memutus perkara. Discretionary power yang dimiliki oleh hakim dianggap sedemikian besarnya sehingga yang terjadi adalah abuse of power yang berujung kepada kesewenang-wenangan menjatuhkan hukuman. Pedoman pemidanaan dianggap sebagai jalan terbaik dalam membatasi kebebasan hakim sehingga objektifitas dan konsistensi dalam memutuskan perkara akan tetap terjaga.

Perjalanan sejarah ide tentang pedoman pemidanaan telah diaplikasikan di beberapa Negara. Dasar dari pembenaran pembuatan ide tersebut adalah teori proporsionate sentencing yang berakar dari pandangan sarjana klasik Beccaria tentang perlunya kesebandingan antara hukuman dengan kesalahan. ${ }^{10}$ Ajaran klasik Beccaria menjelaskan menjelaskan dua prinsip dasar penjatuhan pidana yaitu ${ }^{11}$ (a) bahwa "let punishment fit the crime" yang mengarahkan pandangan bahwa pemidanaan harus mampu mencegah terjadinya kejahatan dan (b) peniadaan discretionary power dari hakim dalam memutus perkara karena hakim adalah corong undang-undang semata. Akan tetapi gagasan ini mendapatkan tentangan dari beberapa pihak karena dianggap akan membatasi hakim dalam menjatuhkan pidana. Suatu pandangan yang lahir dari Mazhab Neoklasik yang melihat banyaknya faktor yang perlu diperhitungkan dalam memutuskan pemidanaan. Verri mencatat bahwa faktor-faktor kondisi fisik, psikis, lingkungan dan latar belakang sosial terpidana merupakan nilai yang dapat menambahkan atau mengurangi jumlah pidana yang dapat dijatuhkan padanya. Oleh karenanya meskipun pandangan Beccaria untuk meniadakan pertimbangan hakim dalam memutus perkara dalam perjalanan sejarah memperoleh penolakan, akan tetapi prinsip "let punishment fit the crime" tetap diterima dalam arti bahwa pemidanaan diarahkan untuk mencapai suatu tujuan pemidanaan dalam pengertian pencegahan dan penanggulangan kejahatan, upaya rehabilitasi serta sarana perlindungan bagi masyarakat.

${ }^{10}$ Beccaria, "Of Crime and Punishment", Translated by Jane Grigson, (New York: Marsilio Publisher, 1996), tanpa halaman.

${ }^{11}$ Ibid. 


\section{Desert Theory: Pemahaman Awal Proporsionalitas}

Teori "desert" banyak merupakan teori yang menggambarkan pemikiran tentang proporsionalitas dalam pemidanaan. Desert theory diterjemahkan sebagai "the dessert rational rest on the idea that penal sanction should fairly reflect the degree of reprehensibleness (that is, the harmfulness and culpability) of the actor conduct". ${ }^{2}$ Pandangan ini menyatakan bahwa beratnya sanksi pidana harus seimbang dengan kesalahan dari pelaku. Teori ini amat berkorelasi dengan adagium "only the guilty ought to be punished" atau dalam literature hokum pidana Indonesia dikenal sebagai asas tiada pidana tanpa kesalahan (geen straft zonder schuld). Karenanya adalah terlarang untuk menjatuhkan sanksi pidana pada seseorang yang tidak bersalah. Dan penjatuhan pidana pun harus diukur berdasarkan besar kecilnya kesalahan yang dibuat oleh seorang pelaku tindak pidana.

Đesert theory mensyaratkan adanya perimbangan antara kesalahan dan hukuman. Sungguh sulit meniali kesalahan karena hal itu merupakan suatu yang abstrak. Ukuran yang dipakai untuk menimbang besar kecilnya kesalahan sangat erat kaitannya dengan jenis pidana yang dilakukannya. Ukuran untuk menyatakan suatu tindak pidana masuk dalam katagori berat atau ringan bergantung kepada dua hal yaitu (a) nilai kerugian materiil yang ditimbulkan sebagai akibat dari tindak pidana yang terjadi atau (b) pandangan atau penilaian masyarakat terhadap suatu perbuatan pada satu waktu tertentu. Oleh karenanya para pembuat kebijakan selayaknya dapat merekam setiap perubahan yang terjadi dalam masyarakat sehingga dapat menakar jenis dan ukuran sanksi yang selayaknya diancamkan atas suatu tindak pidana tertentu. Dalam pandangan retributif klasik, ajaran lex talionis memperkenalkan konsep "eye for an eye" yang kemudian banyak dipadankan dengan desert theory. Akan tetapi Von Hirsch dan Andrew Asworth mencatat adanya perbedaan tujuan dari kedua teori ini dimana ide teori ini lebih kepada pertimbangan proporsionalitas penjatuhan hukuman dari pada perimbangan pembalasan yang dapat dilakukan atas suatu tindak pidana.

\section{Memaknai Proporsionalitas}

Pemaknaan proporsionalitas berdasarkan kepada desert theory sesungguhnya sangat berbeda antara pandangan secara teoretis dengan praktek dilapangan. Para

12 Andrew Von Hirsch and Andrew Asworth, "Proportionate Sentencing: Explorate Principle", (New York: Oxford University PressInc, 2005), hal. 4. 
hakim dalam membuktikan unsur kesalahan dihadapkan pada fakta-fakta yang merupakan variable-variabel yang harus diperhitungkan guna mengukur kesalahan seseorang. Setiap perkara pidana memiliki variabelnya sendiri yang berbeda dengan perkara lainnya. Oleh karenanya penjatuhan pidana menjadi begitu variatif dan makna proporsionalitas menjadi relatif. Teori proporsionalitas dalam pemidanaan bertujuan untuk meminimalisir ketidak adilan yang disebabkan oleh karena adanya perbedaan penjatuhan jenis atau besaran sanksi pidana. Dalam satu perkara tertentu barangkali hakim menilai bahwa pidana ringan yang dijatuhkannya seimbang dengan kesalahan seorang pelaku. Sementara dalam perkara lainnya baru dikatakan proporsional bila jenis pidana beratlah yang dilakukan.

Tidak adanya acuan yang dapat menjadi panduan hakim dalam memutuskan besar kecilnya pidana yang dijatuhkan menjadi subyektifitas hakim merupakan satusatunya ukuran. Apalagi dengan besarnya jarak antara skala maksimal dan minimal yang ditentukan undang-undang. Abuse of power yang dikhawatirkan terjadi akibat adanya discretionary power yang sedemikian akibat jaminan yang diberikan undangundang atas kebebasan hakim dalam menangani perkara pidana menjadi demikian terbuka. Banyak Negara yang kemudian membuat suatu strategi kebijakan baru dalam menentukan mekanisme yang menjadi pedoman hakim dalam mengukur besaran sanksi yang dijatuhkan sehingga problema penjatuhan sanksi pidana sebagaimana dipaparkan diatas dapat diminimalisasi. Sekurang-kurangnya terdapat tiga strategi penjatuhan sanksi pidana yang dikembangkan diberbagai Negara didunia yaitu:

\section{a. Indeterminate sentence;}

Suatu sistem penjatuhan pidana yang tidak didasarkan pada satu satuan waktu yang pasti, akan tetapi penjatuhan sanksi ini menentukan "range" waktu tertentu misalnya dipidana paling singkat 3 tahun dan paling lama 6 tahun. ${ }^{13}$ Jadi dalam hal ini terpidana harus menjalani pidana antara 3 sampai 6 tahun, dimana lama waktu ini akan tergantung kepada si terpidana itu sendiri.

Secara positif, hal ini dianggap akan mampu memicu terpidana untuk dapat memicu dirinya bersikap baik dan mematuhi segala kewajiban serta pekerjaan yang dibebankan padanya. Ia akan berusaha untuk dapat mengusahakan kebebasannya sesegera mungkin sesuai dengan jangka waktu minimal yang

${ }^{13}$ G.Larry Mays dan L.Thomas Winfree Jr., "Contemporary Corrections", Second Edition, (Belmont: Wadsworth/Thomson Learning, 2002), hal. 75. 
ditentukan dalam putusan yang dijatuhkan kepadanya. Dalam wacana ini, paradigm pemidanaan yang ada dapat dilihat dalam dua pon penting yaitu:

a) Pemidanaan bukan merupakan sarana menakut-nakuti akan tetapi merupakan sarana pencerahan dimana diharapkan bahwa pelaku menyadari adanya kebaikan bagi dirinya yang dapat diupayakannya sendiri;

b) Adanya upaya perbaikan yang terjadi dengan sendirinya atas dorongan yang muncul dari harapan untuk dapat membebaskan dirinya sendiri dari pada mekanisme rehabilitasi yang diusahakan oleh institusi.

Permasalahan yang sering muncul dari mekanisme pemidanaan seperti ini adalah:

(1) Fokus pemidanaan terpaku pada mengusahakan pembebasan secepatcepatnya sehingga tujuan rehabilitasi atau perbaikan menjadi terabaikan;

(2) Bagaimana institusi koreksi (di Indonesia dilaksanakan oleh Lembaga Pemasyarakatan) mengukur kelayakan dari terpidana untuk keluar lebih awal. Seringkali muncul dalam praktek (di Negara yang sudah menerapkan mekanisme ini) dimana terpidana merasa haknya untuk dibebaskan tetapi pihak otoritas menilai bahwa terhadapnya harus menjalankan pidana lebih lama dari batas minimal yang dijatuhkan hakim bahkan sampai kepada batas maksimal.

(3) Ketiadaan ukuran yang pasti untuk menilai kelayakan pembebasan pelaku menyebabkan petugas kerap mengambil keputusan untuk memperpanjang jangkan waktu pemidanaan bagi terpidana dari yang seharusnya.

(4) Tujuan yang ingin dicapai hakim ketika menjatuhkan pidana dalam jangka waktu tersebut belum tentu ditangkap oleh petugas dengan baik sehingga ukuran penilaian atas kelayakan pembebasan tersebut menjadi bias;

(5) Putusan pembebasan akan terpaku pada laporan petugas yang karena ketiadaan ukuran akan mung terbaca berbeda oleh hakim pengawas atau komite penilai khusus yang dibentuk untuk memutuskan waktu pembebasan kepada pelaku.

\section{b. Determinate sentence;}

Dalam model determinate sentence, keterikatan hakim dalam menjatuhkan pidana didasarkan pada ketentuan adanya satuan waktu yang pasti oleh 
undang-undang. Hakim dalam hal ini harus memilih diantara pilihan-pilihan yang ada, misalnya dalam kasus pencurian, maka undang-undang menetukan besaran sanksi yaitu 3,4,5 tahun. Biasanya hakim akan menjatuhkan pilihan pada yang ditengah-tengah yaitu 4 tahun, karena bila ia memilih 3 tahun tentunya harus ada alasan yang memperingan pidana atau bila ia memilih 5 tahun harus ada faktor pemberat yang menjustifikasi putusannya itu.

Kelemahan dari sistem ini adalah bahwa seolah-olah undang-undang melihat semua perkara pidana itu sama. Dan penulis menyadari bahwa kacamata kuda halim dalam memutus suatu poerkara akan selalu digunakan. Discresionary power bagi hakim seolah diminimalisir bahkan nyaris ditiadakan. Hakim tidak lagi memiliki kebebasan dalam memutus perkara.

\section{c. Mandatory sentence}

Bila indeterminate dianggap terlalu luas, maka determinate sentence dianggap terlalu rigid. Dalam hal ini mandatory sentence merupakan mekanisme penjatuhan sanksi pidana yang ditentukan oleh undang-undang berdasarkan skala tertentu. Biasanya ditentukan berdasarkan skala minimal lamanya pidana (penjara) yang harus dijalani pelakunya. Perumusan pemidanaan dengan menggunakan mekanisme ini berdampak pada berkurangnya "sentencing discretion" dari para hakim.

\section{d. Sentencing Guidelines}

Mengacu pada permasalahan dan paparan diatas, maka dalam catatan Von Hirsch, sentencing guideline telah dirumuskan dibeberapa Negara dan telah ditungkan dalam bentuk regulasi seperti di beberapa negara bagian di Amerika Serikat, ${ }^{14}$ yang kemudian menjadi model atau acuan dari negeranegara lainnya. ${ }^{15}$ Finlandia ditahun 1976, atau Swedia pada tahun 1988, mengadopsi model ini dengan membuat beberapa penyesuaian berkaitan dengan ukuran yang dipakai. ${ }^{16}$ Sementara Kanada mengadopsi prinsip-prinsip

\footnotetext{
${ }^{14}$ Pada tahun 2001 tercatat 18 negara bagian telah memberlakukan pedoman pemidanaan ini. Robin I Lubitz dan Thoman W Ross, Sentencing Guidelines: Reflection on the Future, Papers From the Executive Sessions on Sentencing and Corrections No.10, US Departmen Of Justice, June 2001.

${ }^{15}$ Andrew Von Hirsch, Ibid.

${ }^{16}$ Ibid.
} 
dasarnya dan kemudian memodifikasi model tersebut sebagai pedoman bagi pemidanaan bagi para narapidana remaja. ${ }^{17}$ Sementara New Zeland melalui sentencing statute mengadopsinya pada tahun 2002 dan menerapkannya bagi narapidana dewasa. ${ }^{18}$

Pembuatan pedoman pemidanaan di Amerika merupakan suatu proses panjang yang didasarkan pada suatu proses mendalam berkaitan dengan praktek pemidanaan yang telah terjadi selama bertahun-tahun. Pedoman pemidanaan ini pada dasarnya dibuat berdasarkan dua variable utama yaitu:

a. Keadaan-keadaan yang meliputi tindak pidana (yang menentukan tingkatan atau level dari tindak pidana tersebut);

b. Catatan kriminal dari pelaku tindak pidana Seperti residive, status buronan, pelaku gabungan tindak pidana dan lain sebagainya.

Sementara variabel tambahan berkaitan dengan sikap pelaku, hubungan pelaku dan korban, jaminan pertanggungjawaban pelaku, luka yang diderita korban, dan lain sebagainya.

Larry Mays dan Thomas Winfree mencatat sejumlah pertimbangan penting adanya perumusan pedoman pemidanaan, ${ }^{19}$ adalah:

a) Patut disadari bahwa memutuskan suatu pemidanaan bagi para hakim merupakan suatu proses yang sulit, karenanya para hakim memibutuhkan bantuan untuk mempermudah tugas tersebut. Asas kebebasan hakim yang melahirkan diskresi yang sedemikian besar telah melahirkan suatu "sentencing disparities", karenanya pedoman pemidanaan menjadi penting untuk memacu keseragaman pemidanaan dan membatasi kemungkinan hakim menggunakan kewenangan memidana yang "tidak pada tempatnya".

b) Pedoman pemidanaan memastikan dipertimbangkannya beberapa faktor penting yang terkait dengan pemidanaan itu sendiri. Dalam hal ini terutama pembedaan antara seorang pelaku pemula dengan mereka yang recidive.

${ }^{17} \mathrm{Ibid}$.

${ }^{18}$ Ibid.

${ }^{19}$ G.Larry Mays dan L.Thomas Winfree Jr., Op. Cit., hal.76-77. 
c) Menjadi suatu kecenderungan dari para hakim di berbagai memicu Negara untuk menjatuhkan pidana dalam skala minimal semata-mata karena pertimbangan subyektif para hakim"

d) Pedoman pemidanaan memang dibuat untuk medorong adanya konsistensi penjatuhan sanksi pidana berdasarkan jenis dan besaran atau lamanya sanksi, berdasarkan faktor-faktor yang menjadi variable dalam penentuannya.

e) Jarang sekali dapat diperoleh suatu penjelasan yang menjadi dasar atau alasan para hakim menentukan besaran atas sanksi yang dijatuhkannya. Dengan adanya pedoman pemidanaan maka pertanyaan mengenai alasan tersebut menjadi tidak dibutuhkan karena pedoman pemidanaan telah menjelaskannya. Adanya pedoman pemidanaan merupakan suatu implementasi dari asas "presumptive sentencing", yang mengedepankan transparansi dan konsistensi dalam menjatuhkan sanksi pidana.

Di Indonesia, problema terbesar dari pemidanaan adalah disparitas yang begitu besar dan beragam sebagaimana telah dinyatakan terdahulu. KUHP memang memberikan kewenangan yang begitu besar kepada hakim dalam menjatuhkan sanksi pidana. Dalam pidana penjara misalnya, Pasal 12 KUHP menentukan skala minimal pidana penjara adalah satu hari. Bandingkan dengan jumlah maksimal pidana penjara yang ditentukan dalam berbagai Pasal dalam buku II KUHP. Rentang antara batas maksimal dan minimal yang begitu besar misalnya 1 hari sampai 15 tahun untuk pembunuhan, 1 hari sampai 5 tahun untuk pencurian, memberikan kewenangan yang luar biasa dari para hakim dalam menjatuhkan sanksi pidana. Alasan perhitungan besaran sanksi pidana yang diberikannya dalam perbagai putusan pun sulit ditemui. Karenanya subyektifitas penilaian hakim menjadi satu-satunya yang digunakan. Secara terbatas, proporsionalitas penjatuhan sanksi pidana di Indonesia telah diupayakan dengan menggunakan strategi pemidanaan seperti menentukan pidana minimal untuk beberapa jenis sanksi pidana dalam beberapa peraturan perundang undangan diluar KUHP seperti dalam Undang-Undang Pengadilan HAM No.26 tahun 2000 yang menentukan pidana penjara minimal 10 tahun dan maksimal 25 tahun. Atau dalam Undang-undang Tindak Pidana Korupsi No.31 tahun 1999 menentukan sanksi pidana penjara minimal 4 tahun dan maksimal 20 tahun. Ketentuan ini dibuat dengan tujuan untuk mengurangi disparitas pemidanaan, serta diperhitungkan untuk dapat mencapai tujuan pemidanaan yang menjadi landasan perhitungan besaran tersebut dari para perumusnya. Meskipun dalam kenyataannya di banyak putusan perkara pelanggaran HAM berat sanksi yang dijatuhkan bahkan dibawah skala minimal yang ditentukan dalam aturan perundang-undangan. 
Pedoman pemidanaan yang dapat ditemuinya dalam KUHP misalnya:

a. Dalam menjatuhkan pidana bersyarat, hakim dibatasi dengan ketentuan dalam Pasal 14a bahwa:

Apabila hakim menjatuhkan pidana paling lama satu tahun atau pidana kurungan,

Kecuali untuk perkara yang menyangkut penghasilan atau persewaan negara atau terkait dengan perkara candu.

Batasan ini menurut penulis masih sangat besar memberikan kewenangan kepada hakim karena pedoman ini menentukan ukuran dapat dipakainya pidana bersyarat adalah pada sanksi maksimal yang dijatuhkan hakim, sehingga masih tetap bergantung pada penilaian hakim.

b. Dalam hal perhitungan besaran sanksi dalam gabungan tindak pidana yang dirumuskan dalam pasal 63 sampai dengan 71 KUHP, namun yang ditentukan dalam hal ini adalah batasan maksimal besaran sanksi yang dapat dijatuhkan hakim. Namun sebagaimana yang dipaparkan diatas, sudah menjadi suatu kecenderungan umum bahwa hakim biasanya menjatuhkan pidana berdasarkan batas minimal atau dalam ukuran yang rendah.

c. Dalam menentukan ukuran konversi atas pidana denda dalam Pasal 30 dimana:

(2) Jika pidana denda tidak dibayar, ia diganti dengan pidana kurungan.

(3) Lamanya pidana kurungan pengganti paling sedikit satu hari dan paling lama enam bulan.

(4) Dalam putusan hakim, lamanya pidana kurungan pengganti ditetapkan demikian; jika pidana dendanya tujuh rupiah lima puluh dua sen atau kurungan, di hitung satu hari; jika lebih dari lima rupiah lima puluh sen, tiap-tiap tujuh rupiah lima puluh sen di hitung paling banyak satu hari demikian pula sisanya yang tidak cukup tujuh rupiah lima puluh sen.

Perhitungan ini tidak dapat menjadi pedoman mengingat nilai mata uang yang telah berubah sejalan dengan perubahan nilai rupiah sehingga nilai konversinya pun menjadi tidak layak dan tidak adil dibandingkan dengan besarnya pidana denda yang ditentukan dalam berbagai aturan perundang-undangan diluar KUHP dan dalam berbagai putusan hakim sebagaimana telah dipaparkan terdahulu. 
Ketentuan tersebut diatas dalam kacamata Muladi bukanlah merupakan pedoman pemidanaan akan tetapi hanyalah aturan pemberian pidana. ${ }^{20}$

Sebagaimana pengalaman diberbagai Negara, merumuskan suatu pedoman pemidanaan bukanlah suatu pekerjaan yang mudah. Berbagai model pedoman pemidanaan berdasarkan strategi perumusan sanksi sebagaimana dikemukakan terdahulu telah dicoba, mulai dari yang sangat ketat hingga yang sangat longgar. Model determinate sentencing yang pernah diterapkan di beberapa Negara bagian di Amerika ternyata tidak memuaskan karena perumusan yang ada telah melupakan beberapa variable yang sesungguhnya penting. Namun model indeterminate sentencing maupun mandatory sentencing juga memiliki kelebihan dan kelemahannya.

Dalam Rancangan KUHP yang ada, para perumus memilih memberikan pedoman pemidanaan yang merupakan checking point bagi hakim yang membantunya dalam mempertimbangkan pemidanaan yang meliputi:

Pasal 55

(1) Dalam pemidanaan wajib dipertimbangkan:

a. kesalahan pembuat tindak pidana;

b. motif dan tujuan melakukan tindak pidana;

c. sikap batin pembuat tindak pidana;

d. apakah tindak pidana dilakukan dengan berencana;

e. cara melakukan tindak pidana;

f. sikap dan tindakan pembuat sesudah melakukan tindak pidana;

g. riwayat hidup dan keadaan sosial dan ekonomi pembuat tindak pidana;

h. pengaruh pidana terhadap masa depan pembuat tindak pidana;

$i$. pengaruh tindak pidana terhadap korban atau keluargakorban;

$j$. pemaafan dari korban dan/atau keluarganya; dan/atau

k. pandanganmasyarakat terhadap tindak pidana yang dilakukan.

(2) Ringannya perbuatan, keadaan pribadi pembuat, atau keadaan pada waktu dilakukan perbuatan atau yang terjadi kemudian, dapat dijadikan dasar pertimbangan untuk tidak menjatuhkan pidana atau mengenakan tindakan dengan mempertimbangkan segi keadilan dan kemanusiaan.

Kata wajib dipertimbangkan menandakan bahwa hal ini tidak bersifat limitatif akan tetapi tidak dapat dikurangi.

${ }^{20}$ Muladi, Op. Cit. 
Pedoman ini dirumuskan bukan untuk menghilangkan disparitas secara mutlak tetapi disparitas yang ada menjadi lebih beralasan. ${ }^{21}$ Sebagaimana yang dipertimbangkan dalam penyusunan pedoman pemidanaan adalah bahwa tujuan perumusan pedoman ini bukan semata-mata untuk menghilangkan disparitas pemidanaan akan tetapi lebih dari itu, untuk menjamin agar tujuan pemidanaan dapat diharapkan tercapai. Akan tetapi pedoman ini belum dapat terbukti efektifitasnya karena hingga saat ini Rancangan KUHP belum juga diberlakukan.

\section{Kesimpulan}

Apapun bentuk dan pilihan yang dibuat, pada akhirnya dengan mengingat kepada teori proporsionalitas pemidanaan maka adanya pedoman pemidanaan menjadi suatu kebutuhan di Indonesia baik bagi para legislator yang merumuskan besaran sanksi dalam aturan perundang undangan maupun para hakim. Hal ini bertujuan:

a. Untuk legislasi

Adanya pedoman perumusan sanksi pidana akan membantu menentukan sanksi yang sepadan dengan kriteria berat ringannya atau tingkat berbahayanya suatu tindak pidana. Hal ini penting sehingga ketidak sesuaian perbandingan antara besaran sanksi pidana dan kualifikasi tindak pidana antar berbagai aturan perundang-undangan dapat dihindari.

b. Untuk para hakim

Suatu pedoman pemidanaan akan dapat membantu para hakim dalam melaksanakan tugas berat dalam menentukan jenis dan besaran sanksi, mereduksi subyektifitas penilaian serta menjamin konsistensi dalam menjatuhkan sanksi pidana.

${ }^{21}$ Ibid 


\section{Daftar Pustaka}

Beccaria, Of Crime and Punishment, Translated by Jane Grigson, New York: Marsilio Publisher, 1996.

Bents, Stanley L. Punishment, in The Encyclopedia of Philosophy, ed. Paul Edwards, New York: Macmillan Publishing Co., 1967.

Blumstein, Alfred, et.al, "Research on Sentencing: The Search for Reform", Volume II (1983), ditelusur melalui <http://book.nap.edu/ openbook_php?record_id=101\& page=9>, diakses tanggal 4 Maret 2011 .

Garner, Bryan A. (Ed), Black's Law Dictionary, 7 edition, St.Paul, Minn, 2000.

Harkrisnowo, Harkristuti. Rekonstruksi Konsep Pemidanaan: Suatu Gugatan Terhadap Proses Legislasi dan Pemidanaan di Indonesia, Orasi Pengukuhan Guru Besar di Universitas Indonesia, Depok: 8 Maret 2003.

Lubitz, Robin I. dan Thoman W Ross, Sentencing Guidelines: Reflection on the Future, Papers From the Executive Sessions on Sentencing and Corrections No.10, US Departmen Of Justice, June 2001.

Mays, G. Larry. dan L.Thomas Winfree Jr., Contemporary Corrections, Second Editions, Belmont: Wadsworth/Thomson Learning, 2002.

Muladi, Kapita Selekta Sistem Peradilan Pidana, Cet.1, Semarang: Badan Penerbit Universitas Diponegoro, 1995.

Von Hirsch, Andrew, and Andrew Asworth, Proportionate Sentencing: Explorate Principle, New York: Oxford University PressInc, 2005. 